\title{
Review of Erwin Dekker's The Viennese Students of Civilization: The Meaning and Context of Austrian Economics Reconsidered. New York: Cambridge University Press, 2016, 216 pp.
}

\section{HARALD HAGEMANN \\ University of Hohenheim}

Erwin Dekker's book, which grew out of his dissertation at Erasmus University Rotterdam, and is published in the renowned series Historical Perspectives on Modern Economics by Cambridge University Press, is an ambitious attempt at studying the work of Austrian economists from the perspective of cultural economics. In contrast to the vast literature on Austrian economics that has been published in recent decades, the work of Carl Menger, Eugen von Böhm-Bawerk, Friedrich Wieser, Ludwig von Mises, Joseph Alois Schumpeter, Friedrich August Hayek, Fritz Machlup, and other economists is not analyzed from the viewpoint of economic theory, but from the cultural or civilizational context in which these scholars lived and shaped their ideas. As Dekker argues with regard to Wieser: "customs, traditions and the governing morality [...] are the most powerful forces in society" (59). In the same mood as his mentor Wieser, Hayek had stated: "Economic laws are no longer natural; they are cultural or civilizational processes" (65).

Dekker opens his work with an introductory chapter, which centrally discusses the work Last Visitors to Pompeii by the Dutch painter Carel Willink (which also covers the front page of the book) to illustrate the pessimistic intellectual mood that prevailed in Vienna already long before World War I. This period-Vienna's "golden autumn"-began after Austria's defeat against Prussia at Königgrätz in 1866, and the subsequent "Ausgleich" with Hungary, which broke the Danube monarchy apart and ended the "golden age" of liberalism that had only just started with the launching of the first liberal constitution in 1861. In analogy to Willink's painting, Dekker argues that the Viennese students of civilization felt that this civilization was worth preserving,

Editors' note: This is a review of a book written by a current editor of this journal. Erwin Dekker joined the editorial board after this review had been commissioned. He has not been involved in editing it. 
but was in decline as a result of a series of crises; and, in the 1930s, increasingly under threat to be destroyed.

Vienna produced a galaxy of creative genius: Gustav Mahler and Arnold Schönberg, Gustav Klimt and Egon Schiele, Sigmund Freud and Alfred Adler, Adolf Loos and Oskar Kokoschka, Ernst Mach and Ludwig Wittgenstein. Although the Danube monarchy had collapsed at the end of World War I, hunger and poverty impaired the living conditions of the masses, and the hyperinflation at the wake of the war contributed to an erosion of the middle classes, the intellectual life continued to flourish in the capital of the former Habsburg empire that was now disproportionally large in relation to the small post-war Austria.

Dekker rightly points out that the context of the Habsburg Empire played an important role, but he overstates his case when he argues that the label "Austrian" is misplaced and should be substituted by "Viennese". In the German language area the terms Österreichische Schule (Austrian school) and Wiener Schule have always been considered as synonymous. The University of Berlin, founded by Humboldt in 1810, has never played as dominant a role in Germany as the University of Vienna, founded in 1365, played in Austria. For example, of 51 scholars in economics who emigrated from Austria in the 1930s, 50 had a PhD degree from the University of Vienna, 13 from before and 37 from after 1918. This shows that the University of Vienna had almost monopolized academic education in Austria, a situation substantially different from the one in Germany.

Career opportunities for outstanding young economists were limited. Economics in the interwar period was still taught at the law faculty, with only three chairs in economics. All three, formerly held by Böhm-Bawerk, Wieser as the successor of Menger (from 1903-22), and the economic historian Carl Grünberg, became vacant between 1919 and 1926. Of the newly appointed professors, only Hans Mayer, as Wieser's handpicked successor, stayed within the tradition of the Austrian school, but his contributions did not make a lasting impact, and his later behavior in the period 1938-45 was morally and politically dubious. The other two chairs were given to Othmar Spann, a reactionary and antisemitic supporter of the corporatist state, who vehemently opposed methodological individualism and instead favoured a holistic intuitive universalism; and Count Ferdinand Degenfeld-Schönburg, who is hardly remembered today. Neither Schumpeter nor Mises, who were the two most qualified candidates from Vienna, well-known internationally and 
in the proper age for being appointed, became professor at the University of Vienna. The signals for the most promising of the younger generation of theoretically inclined economists were clear. They had to look outside Austria for professorships. Even in the years of the Republic, the law faculty was not inclined to offer substantial career prospects to Jews, social democrats, liberals, women, or other "suspicious" persons. Machlup was even denied the habilitation. This explains why the emigration of scholars began long before the “Anschluss" to Nazi Germany in March 1938.

Furthermore, it also explains why a great part of the intellectual debates took place outside the institutional structures of the university, in the famous Viennese circles. In chapter 2 of his book, Dekker rightly emphasizes the important role of these "Wiener Kreise" in cultivating economic knowledge (see page 33, where Dekker lists eight important circles together with the main participants and indicating relevant overlaps and differences.) The main emphasis of these circles was different: such as philosophy in the Wiener Kreis of Moritz Schlick, Rudolf Carnap and Otto Neurath; economics in the Mises seminar; or mathematics in the Colloquium of Karl Menger. One common element, however, typical for intellectual life in Vienna and enhanced by the fact that the debates took place outside disciplinary boundaries, was that the members had a strong interest in philosophy, politics, economics, mathematics, law, literature, music, and the arts. The Geistkreis, founded by Hayek and Herberth Fürth in the early 1920s, typifies this, and it is expressed in figures such as Alfred Schütz or in the verses of Felix Kaufmann. Dekker emphasizes the interdisciplinary discourse in the various Viennese circles and the fact that their intellectual concerns were driven as much by political and social concerns as personality.

However, there was not only mutual inspiration and identity-forming within the circles, but also rivalry, and scientific as well as political differences. Methodological individualism is widely considered as an essential component of Austrian economics. Emphasis on the subjective theory of value is typically a key element of most of the Viennese students of civilization. As one notable outcome, first, Mises launched the socialist calculation debate in the German-language area in the 1920s with his famous thesis that economic calculation in a socialist commonwealth is impossible, because there is no price formation on free markets. And, later, Hayek was involved in the controversial British version of the debate with Lange, Lerner, and Dickinson in the 1930s. 
However, leading Austro-Marxists such as Otto Bauer and Rudolf Hilferding had been fellow students of Mises (and Schumpeter) in BöhmBawerk's seminar, and it was Otto Neurath who was among the first main critics of Mises in "red" Vienna. Morgenstern, on the other hand, objected against the political nature of the works of Mises as well as of the Austro-Marxists.

Subjectivism took a special blend in the elite theories of Wieser and Schumpeter who attributed a key role to the dynamic entrepreneurs in promoting economic development. Emphasis on entrepreneurship, tastes and preferences, the concept of opportunity costs, marginalism, and the time structure of production are normally considered as essential components of Austrian economics. Dekker reflects on the tendency among "Austrian" economists in America to place the work of Schumpeter and the later work of Wieser outside the Austrian school because they represent a deviating current. I think Dekker is right to disagree with this assessment.

It is a pity, however, that he almost completely abstains from economic theory. Fragments are contained in two boxes on "the case of interest" and "the socialist-calculation debate revisited" (85-86), but emphasis is given to the "moral effects of markets". In that sense, box 1 ends with the statement: "A relatively low interest rate can then be interpreted as a sign that people are relatively easily motivated to abstain, and the Viennese students of civilization did not hesitate to consider low interest rate as a sign of an advanced civilization." This is true if the low rates of interest would reflect time preferences of individuals, but definitely not if they are the consequences of easymoney policies of central banks, whether by Draghi's ECB in the period 2010-17, or earlier on by Greenspan's Fed. It is not difficult to imagine Viennese students of civilization such as Mises and Hayek, whose "Austrian" theories of the business cycle are essentially monetary overinvestment theories, among the fiercest critics of such modern monetary policies. Monetary factors cause the cycle but real factors constitute it. Dekker refers to Menger's goods of higher order several times, indicating thereby the importance of the time dimension, but he does not enter into a discussion about the Austrian theory of capital, shaped by Böhm-Bawerk, and integrated as an important element in Hayek's business-cycle theory.

Instead, emphasis is placed on markets as fundamental cultural institutions, indispensable for informed decision-making. Moreover, it 
creates moral effects by taming animal spirits and executing a disciplinary function. Dekker rightly points out that "Mises and Hayek... believe that markets are the central elements of our civilization, both as products of civilization, and as means to preserve that civilization" (89). Dekker repeatedly puts emphasis on restraints, or "strains of civilization", due to individuals' necessary submission to impersonal rules.

Dekker has a special chapter (chap. 6) on the "therapeutic nihilism", widespread among Viennese students of civilization, which he confronts with social engineering or Keynes's famous statement where he compares economists with dentists who could cure a disease successfully. In contrast, therapeutic nihilism is "diagnosing social ills without prescribing remedies for them" (111). Now, medicine metaphors were quite common in business-cycle theories-with expressions such as 'diagnosis' or 'pathology' of the crisis, and 'therapy' being used prominently in the crisis theory of Wilhelm Roscher, to whom the founder of the Austrian school of economics, Carl Menger, had dedicated his Principles. For the Viennese students of civilization, it creates one of several tensions. Should one maintain the role of a detached observer, who passively looks at and analyzes the patient who is incurably ill? This sentiment is expressed most cynically in Schumpeter's statement: "If somebody wants to commit suicide it is a good thing if a doctor is present" (121). Or, should one actively intervene politically to avoid the worst?

In the Great Depression of the 1930s, economic and political liberalism was in its greatest crisis. This crisis manifests itself not only in Austria and Germany, where Ordoliberalism developed as a response to the challenges of the devastating economic and political conditions. Interestingly, we can also observe a tension here between the members of the Frankfurt Institute for Social Research, who, as a kind of left-wing analogon to the extreme liberal Viennese students of civilization, remained mainly in the role of passive observers and analysts of the collapse of civilization; and a scholar such as Adolph Lowe, who, like Norbert Elias, was at the Goethe University in Frankfurt until he was dismissed in 1933, when the Nazis came to power. Lowe, like Keynes, was a social liberal, always actively engaged in reformist policies and in fighting for the defense of the democratic Weimar Republic.

From 1926-30, Lowe served as the head of a new research department of statistical international economics and trade cycles at the 
Kiel Institute of World Economics. His questioning the compatibility of the incorporation of business cycles within the prevailing equilibrium theory became a main challenge for Hayek, who became the founding director of the Austrian Institute of Business Cycles in Vienna in 1927, as chapter 1 of Hayek's Monetary Theory and the Trade Cycle (1933) indicates. Most interesting in Dekker's context, however, is The Price of Liberty (1937), written in British exile, in which Lowe inquired into the conditions of political freedom. Here, the author is a shrewd historical, political, and sociological observer praising "spontaneous conformity" of liberal Britain as "the only mode of life through which a large-scale society can reconcile the conflict between freedom and order" (Lowe $1937,6)$. The price of liberty is individuals' readiness to conform to particular constraints and controls that are manifested as structures, institutions and rules. The functioning of the latter depends on subjective factors such as the understanding and approval of their purpose by those who are restrained.

Many of these topics reappear in Lowe's last book Has Freedom a Future? (1988), which deals with the conditions under which freedom can be established and maintained vis-à-vis the radical transformation to which contemporary Western society is exposed. This concern with a viable order, both stable and free, permeated Lowe's entire work. Emphasis is on the revitalization of the Western tradition properly understood; for example, the individualism rooted in social responsibility. What is at stake here is the problem of balancing the private and the public domains, where the latter is conceived as the guardian of viability of the former. This explains his plea for a new communal ethic in Has Freedom a Future? Lowe is considered by Kenneth Boulding-whose reflections on economics as a moral science figure prominently in Dekker's book (105ff.)—as "one of the few people in the world today who deserves the title of economic philosopher" (Boulding 1965, 139, my italics). It is a pity that Dekker does not compare Hayek with Lowe. In Lowe's work, like in that of other social scientists at the Goethe University in Frankfurt in the second half of the Weimar Republic, disciplinary boundaries did not exist, just as in the intellectual environment of the Viennese students of civilization in the interwar period.

Dekker's attempt has some similarities with Wittgenstein's Vienna by Janik and Toulmin (1973), who placed the work of the famous philosopher into the life and culture of his native city to better 
comprehend his work. To a great extent, Dekker succeeds in arguing in favour of studying economics and the history of economic thought from a cultural point-of-view. It is not surprising that in a project like this many open questions remain. But it has to be stated that the author covers and manages a great amount of the relevant literature. Thus, Dekker also emphasizes that in their postwar works, Viennese students of civilization, such as Hayek and Popper, have "reconceptualized the future as open, and its course as a shared responsibility for mankind" (152). Sick patients clearly favour doctors who propose active treatments to cure the disease and disdain therapeutic nihilists. This is a main explanation for Keynes's success in the Great Depression over economists such as Hayek and Mises who were preaching that the market and the private sector are best left alone to heal themselves. Dekker elucidates that Hayek's engagement in the Mont Pèlerin Society does not only reflect the tradition of the Viennese students of civilization in providing a platform for scholarly debates transgressing disciplinary boundaries, but also indicates a more activist stance to promote (neo)liberal policies.

Hansjörg Klausinger (2006) has shown well, based on four of the leading representatives of the Austrian School (Haberler, Hayek, Machlup and Mises), how the emigration to the United States contributed to a process of de-homogenization. This process reflects different processes of acculturation and stretches across the full range from perfect assimilation to isolation, and niche cultures, as a consequence of the fact that "the Austrians drew on a specific tradition that was rather alien to Anglo-Saxon economists" (Klausinger 2006, 627). Mises was alienated by the rise of econometrics and mathematical economics after the war, and between 1945 and 1969 offered a seminar at New York University in the style of his earlier private seminar in Vienna, thereby at the same time an outsider to the mainstream of economics and instrumental in creating an Austrian School in America. The others, as well as Morgenstern and Schumpeter, on the other hand, made careers at leading universities. But some of their main works, such as Hayek's The Constitution of Liberty (1960) or Machlup's pioneering study The Production and Distribution of Knowledge (1962), which emphasizes the crucial role of knowledge and information for a society, remain firmly within the tradition of the Viennese students of civilization. Dekker addresses all these aspects well, which makes his book worth reading and stimulates further reflections on the conditions 
of founding and maintaining an international civil society, in the present and in the future.

\section{REFERENCES}

Boulding, Kenneth E. 1965. "Is Economics Obsolescent?" Scientific American 212 (5): 139-143.

Hayek, Friedrich A. 1933. Monetary Theory and the Trade Cycle. London: J. Cape.

Hayek, Friedrich A. 1960. The Constitution of Liberty. Chicago: Chicago University Press.

Janik, Allan and Stephen Toulmin. 1973. Wittgenstein's Vienna. New York: Simon Schuster.

Klausinger, Hansjörg. 2006. “'In the Wilderness': Emigration and the Decline of the Austrian School." History of Political Economy 38 (4): 617-664.

Lowe, Adolph. 1937. The Price of Liberty. London: Hogarth Press.

Lowe, Adolph. 1988. Has Freedom a Future? New York: Praeger.

Machlup, Fritz. 1962. The Production and the Distribution of Knowledge. Princeton University Press.

Harald Hagemann is Professor Emeritus of Economic Theory at the University of Hohenheim, Stuttgart, Germany. He is also a Life Member of Clare Hall, University of Cambridge. In 1999/2000, he was Theodor Heuss Professor at the Graduate Faculty of Political and Social Sciences at the New School for Social Research in New York. He formerly taught at the University of Bremen, Kiel, and the Free University of Berlin. He was also a visiting Professor at the Universities of Bologna, EAFIT Medellin, Graz, Linz, Lyon 2, Meiji University Tokyo, Nice, Paris I Pantheon-Sorbonne, Strasbourg and Sydney. His main research covers growth and structural change, technological change and employment, business cycle theory and the emigration of German-speaking economists during the Nazi period. He is also an Honorary Past President of the European Society for the History of Economic Thought (ESHET). Since 2013, he is the Chairman of the Keynes-Gesellschaft. Contact e-mail: <harald.hagemann@uni-hohenheim.de> 